\title{
Piktybinés pleuros mezoteliomos diagnostika ir gydymas
}

Neringa Vagulienė, doc. dr. Marius Žemaitis, Mindaugas Vaitkus, doc. dr. Skaidrius Miliauskas KMU Pulmonologijos ir imunologijos klinika

Reikšminiai žodžiai: pleuros mezotelioma, diagnostika, gydymas.

Santrauka. Straipsnyje aptariami piktybinės pleuros mezoteliomos diagnostikos ir gydymo principai.

Piktybinė pleuros mezotelioma (PPM) - piktybinis navikas, augantis iš pleuros mezotelio ląstelių. Tai reta liga, tačiau sergamumas pastaraisiais metas dideja ne tik Lietuvoje, bet ir Europoje, manoma, kad ligos atvejų daugès ateinančių dešimties metų laikotarpiu [1]. Pagrindinis PPM patogenezès rizikos veiksnys - asbestas, net $62-85$ proc. susirgusių asmenu turëjo profesini kontaktą su asbestu. Skiriamos dvi pagrindinès asbesto rūšys, kurių kancerogeniškumas skirtingas: serpentinai ir amfibolai [2]. Latentinis periodas nuo ekspozicijos iki mezoteliomos simptomų tęsiasi 30-40 metų, todèl liga dažniausiai nustatoma vyresniems kaip 60-70 metų žmonẻms [3, 4]. Kiti mezoteliomos etiologiniai rizikos veiksniai yra spindulinis gydymas, Simian Virus (SV40), organiniai chemikalai (poliuretanas, polisilikonas ir kt.), erionitas, genetiniai veiksniai (GSTM1, NAT2 pažaidos), jatrogeninis pneumotoraksas TBC gydyti, idiopatinis. Skiriami šie profesiniai ir aplinkos veiksniai: asbesto pramonè (kasimas, malimas, asbesto cemento gamyba ir transportavimas, izoliacijos ir asbesto produktu pramonè, asbesto tekstilè), laivininkystè (laivų statymas, ardymas, uosto krovos darbai), geležinkelių priežiūra [5]. Vyrai suserga dažniau nei moterys. Mirtingumas didelis, taikomi gydymo metodai nèra efektyvūs.

Skiriami trys mezoteliomos histologiniai tipai:

- epitelioidinè (50-70 proc.);

- mišri dvifazè (20-25 proc.);

- sarkomatoidinè ar fibrosarkomatoidinè (7-20 proc.). Epitelioidinio histologinio tipo mezotelioma siejama su geresne prognoze, o sarkomatoidinè mezotelioma yra blogesnès prognozès navikas.
Sergant piktybine pleuros mezotelioma, simptomai būna nespecifiški ir pasireiškia tik tada, kai liga jau įsisenėjusi. Dusulys ir krūtinès ląstos skausmas - pagrindiniai simptomai, kurie pasireiškia daugeliui pacientų ir yra susiję su pleuritu. Kosulys, silpnumas, svorio kritimas pasitaiko rečiau. Kartais būna spontaninis pneumatoraksas, susidaro poodinių mazgelių punkcijų ar torakotominių randų vietoje. Neabejotina, kad asbestas yra pagrindinis PPM rizikos veiksnys, todèl labai svarbu išsiaiškinti, ar pacientas yra turèjęs sąlyti su asbestu.

Krūtinès ląstos rentgenogramoje matyti skysčio vienos pusés pleuros ertmèje, pasislinkęs tarpuplautis, difuziškai sustorejjusi pleura, gali būti asbesto sąlygotu pleuros apnašų ar kalcinatų, šonkaulių destrukcija. Atlikus spiralinę krūtinès ląstos KT, įtarti PPM reikètų, kai matyti:

- ištisinis pleuros pažeidimas;

- mazginis pleuros sustorejjimas;

- daugiau kaip $1 \mathrm{~cm}$ sustorèjusi pleura;

- išplitimas i tarpuplaučio pleurą.

Šiuo tyrimu gali būti nustatyta ir tokių pokyčių: pleuros apnašos, skystis pleuros ertmèje, tarpskiltinès pleuros sustorèjimas dèl fibrozès, naviko ar skysčio pažeistos krūtinès ląstos pusès apimties sumažejjimas, metastazès plaučiuose, išplitimas ị krūtinès ląstos sieną, tarpuplauti ar limfmazgius, atokiosios metastazés. Magnetinio rezonanso tomografija (MRT) nèra rutininis tyrimas - jis atliekamas tada, kai planuojamas radikalus operacinis gydymas, nes šiuo tyrimu galima geriau įvertinti naviko išplitimą ị diafragmą ir krūtinès ląstos sieną nei spiraline krūtinès ląstos KT. Naviko 
išplitimui ịvertinti naudojama ir pozitronų emisijos tomografija (PET). Šio tyrimo jautrumas - 96,8 proc., specifiškumas - 88,5 proc. Vis dèlto apie 80 proc. atvejų PPM diagnozuojama vèlyvos stadijos [6].

Pleuros punktato citologinis tyrimas yra vienas iš diagnostikos metodų. Šiuo tyrimu PPM diagnozè nustatoma nuo 30 iki 50 proc. atvejų [7]. Vis dèlto „auksinis standartas" tebèra pleuros biopsija ir bioptato imunohistocheminis tyrimas. PPM diagnozei nustatyti naudojami šie žymenys: kalretininas (CALRT) ir epitelinis membranos antigenas (EMA). Pagrindinis PPM diagnozès nustatymo sunkumas - atskirti mezoteliomą nuo adenokarcinomos [8].

Pastaraisiais metais skelbiami duomenys apie baltymų mezotelino (jautrumas $-80-83$ proc., specifiškumas - 80-100 proc.) ir osteopontino (jautrumas -77 proc., specifiškumas - 85 proc.) koncentracijos padidejimą kraujo serume sergant PPM, tačiau šių žymenų vaidmuo diagnostikoje dar nèra iki galo aiškus.

PPM diagnozei nustatyti ar išplitimui įvertinti taikomos ir chirurginès procedūros: vaizdo torakoskopija (VATS), atviroji pleuros biopsija per pjūvị, mediastinoskopija. Torakoskopija taikytina, kai mezoteliomos diagnozès nustatyti nepavyksta atlikus pleuros skysčio citologini tyrimą ar pleuros adatinę biopsiją, nes šių tyrimų jautrumas yra nepakankamas (1 lentelè).

İvertinti PPM išplitimą būtina, kad būtų parinkta tinkama gydymo taktika bei nustatyta ligos prognozè. Nuo 1995 metu vadovaujamasi IMIG (angl. International Mesothelioma Interest Group) piktybinès pleuros mezoteliomos išplitimo klasifikacija (2 lentelè) $[9,10,11]$.

\section{GYDYMAS}

Nustačius PPM diagnozę nedelsiant turi būti pradètas gydymas. Kokią gydymo taktiką taikyti, turi būti sprendžiama daugiadisciplinio pasitarimo metu analizuojant šiuos klausimus: piktybinio pleurito gydymą, spindulinio gydymo vietą, radikalaus operacinio gydymo galimybę, chemoterapiją ir simptomų gydymą. Mezoteliomos gydymas priklauso nuo naviko išplitimo (IMIG klasifikacija, stadija), ligonio funkcinès būklès, kvėpavimo sistemos funkcijos, gretutinių ligų, kūno masès sumažèjimo bei kitų prognozès veiksnių. Radikalus chirurginis gydymas kartu su adjuvantine chemoterapija ir spindulinis gydymas yra PPM gydymo pagrindas $[12,13,14]$.

\section{Chirurginis gydymas}

Dèl PPM chirurginio gydymo reikšmès vis dar diskutuojama. Skiriamas radikalus ir paliatyvus PPM chirurginis gydymas. Priimtos dvi radikalaus gydymo procedūros: ekstrapleurinè pulmonektomija (EPP) ir pleurektomija/dekortikacija. EPP metu pašalinama pasieninė ir plautinè pleuros, plautis, perikardas ir tos pusès diafragma. Po EPP komplikacijų ir mirštamumo rodikliai dideli: siekia nuo 10 iki 20 proc. [15]. Naujausių tyrimų duomenimis, EPP ir kokybiška po-
1 lentelè. PIKTYBINÉS PLEUROS MEZOTELIOMOS INVAZINIA TYRIMO METODAI

\begin{tabular}{ll}
\hline Tyrimo metodas & Diagnostinė verte் \\
\hline Torakocentezė ir citologinis ištyrimas & $10-30$ proc. \\
Pleuros biopsija & $25-39$ proc. \\
Pleuros biopsija, kontroliuojama KT & $60-85$ proc. \\
Vaizdo torakoskopija/torakotomija & $90-97$ proc. \\
\hline
\end{tabular}

Atviroji pleuros biopsija - auksinis standartas, vaizdo torakoskopija - mažiau invazinis metodas nei torakotomija.

2 lentelè. PIKTYBINÉS PLEUROS MEZOTELIOMOS IŠPLITIMO KLASIFIKACIJA (IMIG)

\begin{tabular}{|c|c|c|}
\hline Stadija & TNM & Paaiškinimas \\
\hline Ia & T1a N0 M0 & $\begin{array}{l}\text { Pirminis navikas, ribotas pasieninès } \\
\text { pleuros kapsulès }\end{array}$ \\
\hline $\mathrm{Ib}$ & T1b N0 M0 & $\begin{array}{l}\text { Kaip Ia stadija + ribotas plautinès } \\
\text { pleuros peraugimas }\end{array}$ \\
\hline II & T2 N0 M0 & $\begin{array}{l}\text { Kaip Ia ar Ib stadija + apimantis } \\
\text { diafragmą ar plautinę pleurą ar po ja } \\
\text { esančią plaučių parenchimą }\end{array}$ \\
\hline III & $\begin{array}{l}\text { Bet kuris T3 M0 } \\
\text { Bet kuris N1 M0 } \\
\text { Bet kuris N2 M0 }\end{array}$ & $\begin{array}{l}\text { Vietiškai išplitęs navikas } \\
\text { Metastazės tos pačios pusės } \\
\text { peribronchiniuose ir plaučių ar vartų } \\
\text { limfmazgiuose } \\
\text { Metastazės subkarininiuose ar tos } \\
\text { pačios pusės tarpuplaučio } \\
\text { limfmazgiuose }\end{array}$ \\
\hline IV & $\begin{array}{l}\text { Bet kuris T4 } \\
\text { Bet kuris N3 } \\
\text { Bet kuris M1 }\end{array}$ & $\begin{array}{l}\text { Vietiškai išplitęs neoperuojamas } \\
\text { navikas } \\
\text { Metastazės priešingos pusės tarpu- } \\
\text { plaučio, vidiniuose krūtų ar viršrakti- } \\
\text { kauliniuose limfmazgiuose, atokiosios } \\
\text { metastazės }\end{array}$ \\
\hline
\end{tabular}

operacinė priežiūra sumažina mirtingumą nuo 5 iki 10 proc. [16, 17]. Po pleurektomijos/dekortikacijos pooperacinių komplikacijų būna mažiau, bet didesnis vietinių atkryčių dažnumas. Pleurektomija/dekortikacija rekomenduojama vyresniems pacientams ar kai liga ankstyvų stadijų. Nèra atlikta jokių perspektyviųjų atsitiktinių imčių tyrimų, skirtų palyginti EPP su pleurektomija/dekortikacija. Plaučiu vėžio tyrimo grupé (angl. Lung cancer Study Group) aprašè, kad pacientụ, kuriems atlikta EPP, ir pacientų, kuriems taikytas neradikalus operacinis gydymas, bendroji gyvenimo trukmé nesiskyrė [18]. Neseniai Flores su kolegomis aprašė tyrimo, kuriame palygino 663 pacientų gydymo EPP ar pleurektomija/dekortikacija rezultatus. Ligonių, kuriems buvo atlikta EPP, pooperacinis mirtingumas buvo didesnis (7 proc.) nei pacientu, kuriems atlikta mažesnès apimties operacija (4 proc.). Bendroji gyvenimo trukmė EPP grupejje buvo mažesnè, tačiau laikas iki atkryčio gerokai ilgesnis nei pleurektomijos/pleurodezès grupeje. Moteriškoji lytis ir sudètinis gydymas siejami su geresniais rezultatais. Tačiau šio tyrimo rezultatu interpretavimas yra ribotas, kadangi išvados pateiktos apibendrinus tik trijų gydymo centrų, kuriuose atliekamos EPP ir pleurektomijos, duomenis [19]. Vis dar lieka neatsakytuc klausimų apie operacijos vietą gydant PPM. 
Esant skausmui ar dusuliu, taikomos paliatyvaus operacinio gydymo procedūros: pleuros ertmès drenavimas ir pleurodezé, pleurektomija, pleuroperitoniné jungtis.

\section{Sudètinis gydymas}

Sudètinis gydymas - tai gydymas derinant kelis būdus. PPM sudètinio gydymo tikslas - sumažinti artimųjų ir atokiųjų metastazių dažnumą po operacinio gydymo ar naviko dydi prieš planuojamą rezekciją. Sugarbaker su bendradarbiais pateikè duomenis dvidešimties metu trukmès tyrimo, kuriame dalyvavo pacientai, gydyti EPP ir po to - nuosekliu chemospinduliniu būdu. Bendros grupès ligoniuc, kuriems atlikta EEP, operacinis mirtingumas buvo mažesnis kaip 4 proc. Vidutinė gyvenimo trukmè - 19 ménesių, 2 metų išgyvenamumas sieke 38 proc., 15 proc. pacientu išgyveno 5 metus. Iki 30 proc. tiriamųjų pasireiške šių komplikacijų: aritmija, kvèpavimo nepakankamumas, aspiracija, PATE [20]. Gydymo derinant operacini, spindulini gydymą ir chemoterapiją duomenys pateikiami ir kitų tyrèjų. Krug su bendradarbiais pateikè duomenis II fazès tyrimo, kuriame 77 pacientams, sergantiems PPM, skyrè keturis kursus cisplatinos su pemetreksedu, o toliau pacientams, kuriems buvo dalinis atsakas ar ligos eiga stabili, atlikta EPP ir po jos skirtas pažeistos pusès spindulinis gydymas. 83 proc. pacientu skirti keturi chemoterapijos kursai, iš jų 87 proc. atlikta EEP operacija. Šiu ligonių vidutinė gyvenimo trukmẻ buvo 17 mènesių [21]. Pastaraisiais metais vis daugiau pateikiama duomenu apie neoadjuvantinès chemoterapijos naudą, kai navikas gali būti operuojamas. Neseniai atlikto tyrimo duomenimis, skyrus neoadjuvantinę chemoterapija cisplatina ir gemcitadinu, o po to atlikus EEP, pacientuc vidutinè gyvenimo trukmè -23 mèn. [22]

\section{Spindulinis gydymas}

PPM - difuziné liga, apimanti dideli plotą ir gretimus organus: plaučius, stemplę, širdi, kepenis. Be to, ji atspari spinduliniam gydymui [23]. Dẻl šių priežasčių spindulinis gydymas, kaip pagrindinis gydymo metodas, sergant PPM nèra rekomenduojamas. Linden su bendradarbiais pateike duomenis tyrimo, kuriame PPM sergančius tiriamuosius suskirstė i dvi grupes. 31 ligoniui skirtas 40 Gy spindulinis gydymas. Šioje grupejje tik vienam ligoniui pasireiške dalinis atsakas, o vidutine gyvenimo trukmè buvo 6 ménesiai [24]. Šiuolaikinis spindulinis gydymas didelèmis spinduliuotès dozèmis taikomas kaip vienas iš sudètinio gydymo metodu po EEP $[25,26]$.

Dažniausiai spindulinis gydymas taikomas krūtinès ląstos skausmui malšinti ar viršutinès tuščiosios venos spaudimo simptomams palengvinti.

\section{Chemoterapija}

PPM yra chemoterapijai gana atsparus navikas, jo gydymo efektyvumą ívertinti labai sunku. Dažniausiai chemoterapijos efektyvumas stebimas atliekant krūtinès ląstos KT, tačiau ir taip ji ịvertinti būna sunku. Gydymo efektyvumo vertinimą pasunkina ir pleuros ertmèje susikaupęs skystis. Nors PPM yra atsparus chemoterapijai navikas, šis gydymo būdas - vienas svarbiausių išplitusios ligos gydymo metodų.

Kadangi liga reta, dèl nedidelio pacientų skaičiaus atlikti III fazès klinikiniu tyrimu sudètinga. Chemoterapija vaistų deriniais yra pažengusios PPM gydymo pagrindas. Naujieji chemoterapijos vaistai prailgina PPM ligonių gyvenimo trukmę ir pagerina gyvenimo kokybę, palyginti su geriausia palaikomąja priežiūra [27]. Pemetreksedas yra citotoksinis vaistas, priklausantis antimetabolinų grupei, kuris sutrikto nukleotinu gamyboje dalyvaujančiuc fermentų (dihidrofoliato reduktazès, timidino sintazès ir glicinamido ribonukleitido formil transferazès) veiklą [28]. Pemetreksedas ir cisplatina yra geriausias pirmos eilès chemoterapijos vaistu derinys ligoniams, kurie serga neoperuojama PPM. Tyrimais neįrodyta, kad yra efektyvesnių preparatų už ši derinị ligoniams, kuriems chemoterapija dar netaikyta. Šios išvados paremtos III fazès tyrimu, i kur buvo įtraukti 456 pacientai, sergantys neoperuojama ir dar negydyta PPM. Ligoniai suskirstyti i dvi grupes: pirmosios grupès tiriamiesiems skirtas pemetreksedo ir cisplatinos derinys, o antrosios - vien cisplatina. Gydant pacientus pemetreksedu ir cisplatina, vidutine gyvenimo trukmé siekè 12,1 mén., o gydant tik cisplatina $-9,3$ mén. $(p=0,02)$ [29]. Chemoterapija pemetreksedu ir karboplatina - efektyvi minèto derinio alternatyva. Kito antifolianto raltitreksedo ir cisplatinos derinys buvo lygintas su monoterapija cisplatina. Pacientų, kuriems skirta vien cisplatinos, vidutinė gyvenimo trukmè buvo 8,8 mén. (PI 7,8-10,8, $\mathrm{p}=0,05$ ), o gydytu raltitreksedo ir cisplatinos deriniu - 11,4 mèn. (PI 10,1-15, p = 0,05) [30]. Šių tyrimų duomenimis, cisplatina ir antifoliantas turètų būti pirmaeilè chemoterapijos schema PPM gydyti.

\section{Gydymo veiksmingumo vertinimas}

Dažniausiai chemoterapijos veiksmingumas vertinamas atliekant spiralinę krūtinès ląstos KT, rekomenduojama vadovautis adaptuota RECIST (angl. Response evaluation criteria in solid tumors) [31]. Vis dèlto ne visada chemoterapijos veiksminguma galima įvertinti spiraline krūtinès ląstos KT. Tiksliau tai galima padaryti pozitronu emisijos tomografija su fluoro deoksigliukoze [32]. Chemoterapijos toleravimas ir toksiškumas vertinamas nuolat.

Vidutinė gyvenimo trukmè sergant PPM yra nuo 8 iki 14 ménesių [33]. Véžio ir leukemijos B grupè ir Europos véžio gydymo mokslinių tyrimų organizacija (angl. The cancer and Leucaemia Group B and European Organization for Research and Treatment of Cancer) pateikè PPM blogos prognozès veiksnius:

- neepitelioidinis histologinis tipas;

- bloga funkcinè būklè;

- krūtinès ląstos skausmas; 
- amžius - daugiau nei 75 m.;

- vyriškoji lytis;

- leukocituc kiekis - 8,3 x $10^{9} / 1$ ir daugiau;

- trombocituc kiekis - $400 \times 10 \% / 1$ ir daugiau;

- LDH kiekis - daugiau kaip $500 \mathrm{TV} / \mathrm{l}$.

Dauguma pacientų, kurie išgyvena ilgiau kaip dvejus metus, serga epitelioidinio histologinio tipo mezotelioma [34].

PPM - reta liga, kurią nustatyti ir gydyti yra sudètinga. Diagnozès nustatymo „auksinis standartas“ torokoskopijos metu paimta biopsija ir jos medžiagos imunohistocheminis tyrimas. Remiantis III fazès klinikinių tyrimų duomenimis, pemetreksedo ir cisplatinos derinys - pirmaeilis chemoterapinis gydymas. Antros eilès chemoterapijos rekomendacijos dar nèra aiškiai apibrèžtos. EPP ar pleurektomija/pleurodezè ir adjuvantinė ar neoadjuvantinè chemoterapija platinos pre- paratų pagrindu vis dažniau taikoma specializuotuose centruose. Vykdomi tyrimai siekiant išsiaiškinti pooperacinio spindulinio gydymo, tiroksinkinazès inhibitorių, angiogenezę slopinančių vaistų reikšmę gydant PPM, tačiau reikšmingų duomenų nepateikiama.

\section{MALIGNANT PLEURAL MESOTHELIOMA DIAGNOSTIC AND TREATMENT}

\section{NERINGA VAGULIENĖ, MARIUS ŽEMAITIS, MINDAUGAS VAITKUS, SKAIDRIUS MILIAUSKAS \\ DEPARTMENT OF PULMONOLOGY AND IMMUNOLOGY KAUNAS UNIVERSITY OF MEDICINE}

Key words: malignant pleural mesothelioma, diagnostic, treatment. Summary. Literary data concerning principales of malignant pleural mesothelioma have been present.

\section{LITERATŪRA}

1. Robinson BW, Musk AW et al. Malignant mesothelioma. Lancet 2005 366: 397-408.

2. Albin M, Magnani $C$ et al. Asbestos and cancer: An overview of curren trends in Europe. Environ Health Perspect 1999; 107, Suppl 2: 289-298.

3. Bianchi C, Giarelli $L$ et al. Latency periods in asbestos - related mesothelioma of the pleura. Eur J Cancer Prie 1997; 6:162-166.

4. Walker AM Loudhlin JE et al. Projections of asbestos - related disease 1980 - 2009. J Occup med 1983;25:409-425.

5. Karbone $\mathrm{M}$, Fisher $\mathrm{S}$ et al.New molecular and epidemiological issues in mesothelioma: role of SV40. J Cell Physiol 1999;180:167-172

6. Kannerstein M McCaugheyv WT et al. A critique of the criteria for the diagnosis of diffuse malinant mesothelioma. Mt Sinai J med 1977;44:485 494.

7. Kent $M$, Rice $D$ et al. Diagnosis, staging and surgical treatment of malignant pleural mesothelioma. Curr Treat Options Oncol. 2008; 9(2-3): 158 170.

8. Segal A, Whitaker D et al. Pathology of mesothelioma. In: Robinson BWS Chahinian AP, eds. Mesothelioma. London: Martin Dunitz, 2002:143-84.

9. RuschVW. A proposed new international TNMstaging system for malignant pleural mesothelioma. From the International Mesothelioma Interest Group. Chest 1995; 108: 1122-1128.

10. Greene FL, Page DL, et al. American Joint Committee on Cancer. Cancer Staging Handbook. 6th Edn. New York, Springer, 2002; p. 6.

11. Wittekind C, Greene FL, et al. Union Internationale Contre le Cancer. TNM Atlas. 5th Edn. Berlin, Springer, 2004; pp. 169-176.

12. Sugarbaker DJ, Jaklitsch MT, Bueno R, et al. Prevention, early detection, and management of complications after 328 consecutive extrapleural pneumonectomies. J Thorac Cardiovasc Surg 2004:128:138-46.

13. Stewart DJ, Martin-Ucar A, Pilling JE, Edwards JG, O'Byrne KJ, Waller DA The effect of extent of local resection on patterns of disease progression in malignant pleural mesothelioma. Ann Thorac Surg 2004;78:245-52.

14. Pass HI, Kranda K, Temeck BK, Feuerstein I, Steinberg SM. Surgically debulked malignant pleural mesothelioma: results and prognostic factors. Ann Surg Oncol 1997;4:215-22.

15. Jensik R, Cagle JE et al. Pleurectomy in the treatment of pleural effusion due to metastatic malignancy. J Thorac Cardiovasc Surg 1963:46:322 330.

16. Law MR, Gregor A et al. Malinant mesothelioma of the pleura : a study of 52 treated and 64 untreated patients. Thorax 1984;39:255-259

17. Pass $\mathrm{HI}$ Kranda $\mathrm{K}$ et al. Surgically debulcedmalignant pleural mesothelioma: results and prognostics factors. Ann Surg Oncol 1997;4:215-222.

18. Rusch VW. Trials in malinant mesothelioma. LCSG 851 and 882. Chest 1994;106:359S-362S.

19. Flores RM, Pass $\mathrm{HI}$ et al. Extrapleural pneumonectomyversus pleurectomy/decortication in the surgical management of malignant pleu-

ral mesothelioma: results in 663 patients. J Thorac Cardiovasc Surg 2008;135:620-626.

20. Sugarbaker DJ, Norberto JJ. Multimodality management of malinant pleural mesothelioma. Chest 1998; 113:61S-65S.

21. Krug LM, Pass $\mathrm{H}$ et al. A multicenter U.S. trial of neoadjuvant pemetrexed plus cisplatin (PC) followed by extrapleural pneumonectomy (EPP) and hemithoracic radiation (RT) for stage I-III malignant pleural mesothelioma (MPM). J Clin Oncol 2007;25. Abstract No.7561.

22. Weder W, Stahel RA et al. Multicenter trial of neo-adjuvant chemotherapy followed by extrapleural pneumonectomy in malignant pleural mesothelioma. Ann Oncol 2007;18:1196-1202.

23. Baldini EH. External beam radiation therapy for the treatment of pleural mesothelioma. Thorac Surg Clin 2004;14:543-8.

24. Linden $\mathrm{CJ}$, Mercke $\mathrm{C}$ et al. Effect of hemithorax irradiation alone or combineted with doxorubicin and cyclophosphamide in 47 pleural mesotheliomas: a nonrandomizedphase II study. Eur Respir J 1996;9:25652672.

25. Rice DC , Stewens CW et al Outcomes after extrapleural pneumonectomy and intensity-modulated radiation therapy for malignant pleural mesothelioma. Ann Thorac Surg 2007;84:1685-1692.

26. O'Rourke N, Garcia JC et al. A randomized controlled trial of intervention site radiotherapy in malignant pleural mesothelioma. Radiother Oncol 2007; 84:18-22.

27. Jassem J, Ramlau R et al.Phase II trial of pemetrexed plus best supportive care in previously treated patients with advanced malignant pleural mesothelioma. J. Clin Oncol 2008;26:1698-1704.

28. Adjei AA. Pemetrexed (ALIMTA), a novel multitargeted antineoplastic agent. Clin Cancer Res 2004;10:427s-4280s.

29. Vogelzang NJ, Rusthoven JJ et al. Phase III study of pemetrexed in combination with cisplatin versus cisplatin alone in malignant pleural mesothelioma. J Clin Oncol 2003;21:2636-2644.

30. van Meerbeek JP, Gaafar R et al. Randomized phase III study of cisplatin with or without raltitrexed in patients with malignant pleural mesothelioma: an intergroup study of the European Organisation for Research and Treatment of Cancer Lung Cancer group and the national Cancer Institute of Canada. J Clin Oncol 2005;23:6881-6889.

31. Byrne MJ, Nowak AK. Modified RECIST criteria for assessment or response in malignant pleural mesothelioma. Ann Oncol 2004;15:257-260.

32. Bury T, Paulius $P$, Dowlati $A$ et al: Evaluation of pleural diseases with FDGPET imaging: A preminary report. Thorax 52:187-189, 1997.

33. Wiggins J. BTS statement on malignant mesothelioma in the U.K 2007. Thorax 2007;62(2): ii1-ii19.

34. Scott B, Mukherjee $S$, Lake R, Robinson BWS. Malignant mesothelioma. In: Hanson $\mathrm{H}$, ed. Textbook of lung cancer. London: Martin Dunitz, 2000:273-93. 